\title{
Pengaruh Kepemimpinan Visioner dan Budaya Organisasi terhadap Kinerja Pegawai di Pemkot Cimahi
}

\author{
Janadi Rammelsbergi Thamrin \\ Politeknik Komputer Niaga LPKIA \\ janadithamrin@yahoo.co.id
}

\begin{abstract}
Abstrak
Kota Cimahi merupakan kota yang sedang tumbuh dan berkembang setelah memisahkan diri dengan Kabupaten Bandung. Pada saat ini terdapat sejumlah permasalahan yang tengah dihadapi oleh Pemkot Cimahi, diantaranya mengenai kurangnya kinerja. Upaya untuk meningkatkan kinerja pegawai dilakukan melalui kepemimpinan visioner dan budaya organisasi. Penelitian ini bertujuan untuk menganalisa bagaimana pengaruh antara kepemimpinan visioner terhadap kinerja pegawai Pemkot Cimahi, serta pengaruh antara budaya organisasi terhadap kinerja pegawai di Pemkot Cimahi. Penelitian ini menggunakan metode deskriptif dan verifikatif. Sumber data diperoleh dari sampel 93 orang pegawai Pemkot Cimahi. Teknik pengolahan data yang dipakai adalah regresi dengan bantuan program SPSS. Berdasarkan hasil penelitian ditemukan bahwa kepemimpinan visioner memberikan pengaruh positif dan signifikan pada kinerja pegawai Pemkot Cimahi. Selain itu ditemukan bahwa budaya organisasi memberikan pengaruh positif dan signifikan pada kinerja pegawai Pemkot Cimahi. Berdasarkan temuan tersebut, Pemkot Cimahi perlu meningkatkan kualitas kepemimpinan visioner dan juga budaya organisasi karena dapat memberikan pengaruh pada kinerja pegawai.
\end{abstract}

Kata Kunci Kepemimpinan Visioner, Budaya Organisasi, dan Kinerja Pegawai

Cimahi is a growing and developing city after the secession from
Bandung regency. At this time there are a number of problems faced by
Cimahi municipal government, among of that about the lack of
performance. The efforts to improve the performance of employees is
done through visionary leadership and organizational culture. The aim
of this research is to analyze how the effect of visionary leadership on
employee performance in Cimahi municipal government, and also the
influence of organizational culture on employee performance in Cimahi
municipal government. This research used descriptif and verificatif
Method. Sources of data obtained from samples of 93 Cimahi municipal
government employees. Data processing technique used is regression
with SPSS. Based on the results of the study found that visionary
leadership has positive and significant effect on employee performance
on Cimahi municipal government. In addition it was found that
organizational culture has positive and significant effect on employee
performance on Cimahi municipal government. Based on these findings,


Cimahi municipal government needs to improve the quality of visionary leadership and organizational culture as it can affect to employees performance..

Kata Kunci Visionary Leadership, Organizational Culture, and Employee Performance

\section{PENDAHULUAN}

Unsur utama dalam manajemen adalah tenaga kerja, sehingga dalam manajemen SDM faktor yang diperhatikan adalah manusianya itu sendiri. Pada saat ini terdapat banyak organisasi yang mulai menyadari bahwa Sumber Daya Manusia (SDM) merupakan permasalahan organisasi yang paling penting, karena SDM mempunyai keterkaitan dengan sumber daya lain di dalam organisasi yang membuat organisasi tersebut dapat berjalan atau berfungsi dengan baik. Pihak manajemen SDM mempunyai peran yang sangat vital dalam organisasi untuk mengelola SDM yang ada sehingga setiap kebijakan dapat dilaksanakan sesuai dengan yang diharapkan oleh organisasi.

Tujuan utama dalam suatu pemerintahan adalah mampu menciptakan masyarakat yang sejahtera. Dalam upaya menyejahterakan masyarakatnya, seorang pemimpin harus mempunyai visi dan misi yang mampu memberikan kesejahteraan bagi masyarakat. Kebijakan yang dikeluarkan oleh pemerintahan harus menunjukkan keberpihakkannya kepada masyarakat. Pada pelaksanaannya pemerintah daerah harus dapat memberikan pelayanan yang baik kepada masyarakat serta tidak mempersulit dalam pelaksanaannya.

Suatu kebijakan tidak akan dapat terlaksana dengan baik jika SDM dalam organisasi tidak mendukungnya. Oleh sebab itu dibutuhkan SDM yang handal. Manajemen Pegawai Negeri Sipil (PNS) menurut UU No.43/1999 pasal 1 merupakan upaya menyeluruh dalam rangka meningkatkan, efektivitas, efisiensi serta derajat profesionalitas dalam menyelenggarakan tugas, fungsi maupun kewajiban dari pihak kepegawaian yang terdiri dari perencanaan, pengadaan, peningkatan kualitas, penempatan, kenaikan jabatan, pemberian gaji, kesejahteraan dan pemberhentian (Sedarmayanti, 2007:371).

Pemerintahan tidak dapat terlepas dari berbagai macam permasalahan. Menurut Thoha (2005:3) secara singkat, permasalahan yang sekarang dihadapi oleh birokrasi pemerintah ialah: a) Lembaga pemerintahan diisi oleh para aparatur sipil negara dengan kemampuannya yang masih kurang profesional, serta besarnya ukuran lembaga birokrasi; b) Mekanisme kerja birokrasi pemerintah masih bersifat sentralistik; c) Pada saat ini pengendalian birokrasi pemerintah masih dilakukan oleh pemerintah itu sendiri; d) Masih adanya KKN sehingga upaya pemerintah dalam rangka menciptakan good governance masih sulit terlaksana; e) Kurangnya bahkan tidak adanya rasa tanggungjawab dari masing-masing aparatur sipil negara; f) Kompetensi dari pejabat struktural banyak yang tidak sesuai dengan kebutuhan; g) Penataan kebutuhan terhadap sumber daya aparatur maupun pada kelembagaan birokrasi yang tidak sesuai.

Pada awalnya Kota Cimahi mempunyai status Kota Administratip (Kotip) yang masih tergabung dalam Kabupaten Bandung kemudian pada tahun 2001 statusnya ditingkatkan menjadi kota otonom. Kota Cimahi memiliki luas wilayah yang relatif kecil, dimana luas wilayah keseluruhannya adalah sebesar 4.025,73 Ha dan terdiri dari tiga Kecamatan, yaitu Kecamatan Cimahi Selatan, Kecamatan Cimahi Utara, dan Kecamatan 
Cimahi Tengah. Meskipun memiliki luas wilayah yang kecil, akan tetapi Kota Cimahi memiliki banyak prestasi dan mendapatkan banyak penghargaan baik itu di tingkat provinsi maupun nasional. Pemerintahan Kota Cimahi juga mendapatkan penghargaan dari Kementrian Dalam Negeri sebagai daerah terinovatif di Indonesia sepanjang tahun 2019. Seluruh prestasi dan penghargaan yang didapatkan Kota Cimahi tidak terlepas dari kerjasama seluruh pihak, baik itu dari pemerintah maupun masyarakat. Keberhasilan yang didapatkan selama itu tidak terlepas dari peranan Wali Kota Cimahi serta para Kepala Dinas dalam memimpin bawahannya sehingga pemerintahan dapat berjalan dengan baik dan pada akhirnya dapat mencapai target yang telah ditetapkan.

Dalam suatu organisasi pemerintah keberhasilan dapat tercermin dari kinerja yang dihasilkan, serta ketercapaian program yang telah ditetapkan. Kinerja merupakan suatu prestasi nyata yang berupa hasil kerja serta peran yang dilakukan oleh seseorang dalam upaya untuk menyelesaikan pekerjaannya (Yuniarsih dan Suwatno, 2008:161). Menurut Rivai (2005:308) hasil dari penilaian kinerja memperlihatkan bagaimana karyawan tersebut dapat memenuhi tuntutan yang telah ditetapkan oleh perusahaan baik dari segi kualitas maupun kuantitas kerjanya.

Sebuah organisasi pemerintahan memerlukan pemimpin yang mempunyai kemampuan untuk mengatur bawahannya agar dapat bekerja dengan baik. Seorang pemimpin dapat dikatakan berhasil apabila ia dapat menemukan cara untuk meningkatkan produksi dan standar perusahaan, bukan hanya seseorang yang selalu memotivasi bawahannya agar selalu giat bekerja. Terdapat enam kemampuan manajerial yang perlu dikembangkan oleh seorang pemimpin pada saat bekerja agar mampu menciptakan kelompok kerja yang efektif dan berkualitas, yaitu : a) Observasi, b) Memonitor kinerja karyawan, c) Pelaksanaan program pengembangan profesional, d) Menunjukkan bekerja pengetahuan dan keahlian, e) Bijaksana dalam pengambilan suatu keputusan, dan f) Kemampuan untuk perilaku dan evaluasi penelitian.

Pada saat ini seorang kepala daerah tidak hanya menjabat secara birokratis. Akhirakhir ini telah terjadi peralihan dari pola kepemimpinan pemerintahan, dimana seorang pemimpin dituntut agar dapat menjadi lebih modern, memiliki inovasi dalam program pembangunan, serta mendukung investasi dan bisnis. Gubernur, Walikota, maupun Bupati menjelma menjadi seorang CEO dalam memimpin pemerintahan daerahnya masing-masing. Dengan menjunjung tinggi nilai good governance dalam mengelola organisasi, perusahaan akan mendapatkan keuntungan, sedangkan pemerintahan daerah akan menghasilkan kebijakan publik yang pro rakyat. Pada dasarnya governance dapat diterjemahkan menjadi tata kelola yang berkaitan dengan interaksi antara pihak pemerintah dengan masyarakat, sedangkan governing merupakan segala kegiatan sosial, administrasi, ekonomi, politik yang dilakukan dalam rangka untuk mengarahkan, mengendalikan, mengelola serta mengawasi masyarakat. Agar dapat mewujudkan good governance melalui reformasi birokrasi, upaya strategis yang telah, sedang dan akan dilakukan antara lain: a) penyiapan peraturan perundang-undangan berkaitan dengan pembahasan pola pikir dan pola budaya; b) penyiapan peraturan perundang-undangan berkaitan pembaharuan sistem manajemen pemerintahan (dari sistem manajemen birokratik ke manajemen wirausaha); c) mengadakan inventarisasi/ pendataan, deregulasi, kaji ulang dan penyiapan peraturan perundang-undangan sebagai pengganti; d) mengadakan reformasi sistem pelayanan peradilan khususnya sistem peradilan kriminal; e) mengadakan percontohan pelayanan prima yang dilakukan oleh Pemda 
Provinsi, Pemda Kabupaten/ Kota dan percontohan pada tingkat dinas/ instansi pelayanan publik yang telah berhasil menerapkan prinsip tata kepemerintahan yang baik dalam praktek penyelenggaraan pemerintah (Sedarmayanti, 2007: 327-329).

Seorang pemimpin harus mampu membawa organisasi yang dipimpinnya untuk mencapai tujuan (visi) sesuai dengan misi yang telah ditetapkan. Untuk itu dibutuhkan pemimpin yang mempunyai pengetahuan yang mumpuni, imajinasi, memiliki visi ke depan dan dapat menggerakkan seluruh sumber daya serta potensi perusahaan agar dapat bergerak menuju tujuan dan cita-cita yang telah disepakati bersama serta dapat dipertanggungjawabkan (Rivai, 2004:322). Visi harus disegerakan agar tetap sesuai dan sepadan dengan perubahan-perubahan yang terjadi di lingkungan.

Pemimpin visioner dengan wibawanya dapat menciptakan suatu keadaan atau iklim kerja yang menyebabkan orang-orang yang tidak bekerja secara etikal akan menyadari hal itu sendiri, menjadi malu hati, dan karena itu akan berusaha memperbaiki kerjanya. Adalah tugas dan tanggung jawab pimpinan untuk menghasilkan, mengelola, mengembangkan, mengaplikasikan dan menyegerakan visi agar selalu mempunyai kemampuan dalam memberikan respon yang cepat pada berbagai macam permasalahan serta tuntutan yang dihadapi oleh organisasi.

Pada suatu organisasi terdapat budaya organisasi yang akan menuntun pegawai untuk bekerja sesuai dengan pola dan kebiasaan dalam organisasi. Budaya organisasi mampu mempengaruhi anggota organiasi dalam hal cara bekerja, persepsi maupun pandangannya. Apakah pegawai akan memperlihatkan semangat, disiplin, ketertarikan, atau hal-hal negatif seperti kurang responsif, malas, apatis, dll. Nilai dan visi yang tercakup dalam budaya organisasi menyediakan makna, tujuan dan komitmen bagi pegawai. Organisasi mempunyai kepribadian, persis seperti individu: bisa tidak ramah atau malah mendukung, bisa kaku atau malah fleksibel, bisa inovatif atau malah konservatif (Robbins, 2006:720). Karyawan yang sudah memiliki budaya organisasi yang tinggi akan termotivasi dalam bekerja, imbasnya, mereka mampu menunjukkan performa dan hasil kerja yang sesuai dengan standar yang ditentukan perusahaan (Sagita, 2018:80).

\section{LANDASAN TEORI}

\section{Kepemimpinan Visioner}

Tujuan organisasi, tujuan kelompok, bahkan tujuan individu dapat tercapai apabila mendapatkan motivasi dari seorang pemimpin melalui gaya kepemimpinannaya. Pengikut yang telah termotivasi akan mencari cara untuk mencapai tujuan untuk mendapatkan kepuasan. Setelah mendapatkan kepuasan maka pengikut tersebut akan berusaha untuk mencapai tujuan tersebut kembali atau agar kebutuhannya dapat terpenuhi. Kepemimpinan visioner merupakan kemampuan untuk menciptakan dan mewujudkan visi yang realistis, dapat dipercaya dan menarik tentang kondisi organisasi di masa yang akan datang masa depan organisasi atau unit organisasi yang terus tumbuh dan meningkat dibandingkan saat ini (Robbins, 2006:473).

Pemimpin visioner berfungsi sebagai: panutan dalam hal moral bagi karyawan lain dan memberikan contoh dalam bekerja dan berperilaku, pengarah, dan berusaha sejalan dengan etika bisnis, nilai-nilai perusahaan, mencapai tujuan bersama, serta mendorong bawahan agar dapat berkontribusi secara nyata dan rasional dalam proses kegiatan penciptaan nilai (Hartanto, 2009:533). Para pemimpin yang memiliki visi adalah pribadi yang memiliki kepribadian (character) yang berdiri tegak di atas prinsip yang kukuh, 
yang secara spesifik mengandung beberapa nilai utama, yaitu: credible, confidence, conscience, courage, consequence, commitment, care, competence, cooperative, conviction, creative, dan communication (Tasmara, 2002:197).

Menurut Robbins dalam Priansa (2015:161) Keterampilan yang diperlukan berkaitan dengan efektivitas dalam peran visioner adalah:

a. Kemampuan untuk menjelaskan kepada orang lain, agar visi yang dimiliki mampu dipahami oleh pengikut, maka seorang pemimpin harus memiliki kemampuan menjelaskan agar mampu dipahami pengikut sehingga visi tersebut dapat tercapai.

b. Mampu untuk mengungkapkan visi yang tidak hanya melalui ucapan melainkan melalui perilaku pemimpin, seorang pemimpin akan menjadi contoh bawahannya oleh karena itu setiap tindakan yang dilakukan pemimpin harus mencerminkan visi yang ingin dicapai

c. Mampu memperluas visi kepada konteks kepemimpinan yang lebih luas, visi harus dapat diterapkan pada organisasi dalam berbagai macam situasi pekerjaan.

Visi harus disegerakan sehingga tetap sesuai dan sepadan dengan perubahanperubahan yang terjadi di lingkungan. Merupakan tugas serta tanggung jawab seorang pemimpin untuk menciptakan, menjaga, mengembangkan, mengaplikasikan dan menyegerakan visi agar selalu memiliki kemampuan dalam memberikan tanggapan yang cepat pada berbagai masalah dan tuntutan yang sedang dihadapi oleh organisasi.

Menurut Komarian dan Triatna (2005:90-93) langkah-langkah kepemimpinan visioner adalah:

a. Penciptaan visi, seorang pemimpin harus mampu menghasilkan ide-ide (visi) berdasarkan kreativitas dan pengalaman yang dimiliki.

b. Perumusan visi, setiap visi yang dihasilkan harus dituangkan dalam sebuah gagasan yang tersusun dengan rapi secara lisan maupun tulisan agar ide-ide tersebut dapat disampaikan dengan baik kepada pengikut.

c. Transformasi visi, merupakan kemampuan untuk membentuk kepercayaan pada stakeholder sehingga akan terbentuk kesetaraan dan rasa memiliki.

d. Implementasi visi, merupakan kemampuan pimpinan dalam menerjemahkan sebuah visi menjadi tindakan nyata sehingga visi tersebut dapat tercapai.

Menurut Nanus dalam Komariah dan Triatna (2005:93-94) ada empat peran yang harus dimainkan oleh pemimpin visioner dalam melaksanakan kepemimpinannya, yaitu:

a. Penentu arah (direction setter), seorang pemimpin visioner akan akan mengarahkan organisasi yang dipimpinnya agar dapat berjalan menurut rencana yang telah ditetapkan untuk mencapai tujuan

b. Agen perubahan (agent of change), seorang pemimpin visioner harus menjadi pelopor inovasi serta mampu membawa organisasinya berubah menjadi lebih baik dengan ide-ide (visi) yang dihasilkannya

c. Juru bicara (spokes person), seorang pemimpin visioner tidak hanya memiliki kemampuan untuk meyakinkan pengikutnya, akan tetapi harus mampu menyampaikan visi organisasinya ke dunia luar sehingga dapat diakui keberadaannya.

d. Pelatih (coach), seorang pemimpin visioner harus mampu membangun tim yang kuat dengan melatih pengikutnya agar dapat bekerja sama untuk mencapai tujuan organisasi yang telah ditentukan. 


\section{Budaya Organisasi}

Secara umum, budaya merupakan kumpulan dari nilai, kebiasaan, tingkah laku, keyakinan, serta sikap yang membentuk sebuah ciri khas dalam sebuah komunitas di dalam masyarakat. Budaya organisasi adalah rentetan dari nilai, kebiasaan, tingkah laku, keyakinan, dan sikap yang dapat membantu anggota organisasi untuk memahami arti dari prinsip-prinsip yang diikuti oleh organisasi tersebut, bagaimana organisasi mengerjakan berbagai macam hal dan apa yang dianggapnya penting (Griffin, 2004:162). Setiap organisasi mempunyai budaya organisasinya masing-masing yang berbeda-beda dan akan menjadi suatu ciri khas dari organisasi tersebut.

Menurut Robbins (2006:721) pada hakekatnya budaya organisasi terdiri dari tujuh karakteristik utama, yaitu:

a. Inovasi pada saat mengambil resiko. Karyawan diarahkan agar selalu inovatif dan berani untuk mengambil resiko.

b. Memperhatikan detail. Karyawan diarahkan agar selalu cermat, mampu menganalisis, memperhatikan detail.

c. Berorientasi pada hasil. Manajemen berfokus pada hasil, bukan pada proses maupun teknik yang dipakai dalam memperoleh hasil.

d. Berorientasi pada orang. Manajemen mempertimbangkan dampak yang terjadi pada orang-orang yang terdapat dalam organisasi.

e. Berorientasi pada tim. Kegiatan dalam organisasi difokuskan pada kerja berdasarkan tim, bukan kerja individu

f. Keagresifan. Setiap anggota dalam organisasi dituntut untuk bekerja secara kompetitif dan agresif, bukan bekerja dengan santai.

g. Kemantapan. Kegiatan di dalam organisasi difokuskan pada mempertahankan kondisi atau keadaan yang ada pada saat ini, bukan mendorong pertumbuhan.

Menurut Rivai \& Mulyadi (2010:373) budaya organisasi mempunyai fungsi sebagai berikut:

a. Budaya mempunyai suatu peran menetapkan tapal batas, artinya budaya mampu menghasilkan perbedaan yang jelas antara satu organisasi dengan organisasi yang lain.

b. Budaya memberikan identitas pada setiap anggota dalam organisasi.

c. Budaya mempermudah munculnya komitmen secara lebih luas dan pada kepentingan individu.

d. Budaya itu menambah kemantapan dalam sistem sosial.

e. Budaya sebagai proses dalam membuat makna dan kontrol yang mengarahkan dan juga membentuk perilaku maupun sikap dari anggota organisasi.

Budaya organisasi yang menjadi ciri khas harus dapat dipertahankan, oleh karena itu terdapat tiga kekuatan yang sangat penting untuk mempertahankan budaya, yaitu:

a. Seleksi. Tujuan nyata dari seleksi yaitu mengidentifikasikan dan merekrut calon karyawan yang mempunyai skill \& knowledge serta kemampuan dalam menyelesaikan pekerjaan yang teradapat dalam organisasi dengan baik.

b. Tindakan manajemen puncak. Berdasarkan apa yang diperintahkan serta bagaimana mereka menunjukkan perilaku, atasan menjunjung tinggi norma-norma menurut garis komando yang mengarah ke bawah berdasarkan struktur organisasi.

c. Metode sosialisasi. Organisasi akan membantu karyawan baru untuk menyesuaikan diri dengan budayanya (Robbins, 2006:730-732). 
Budaya dapat dipertahankan dengan memberikan penghargaan dan mempromosikan orang yang berlaku konsisten dengan budaya yang ada dan dengan menyuarakan budaya melalui simbol-simbol, cerita-cerita, pahlawan-pahlawan, sloganslogan, perayaan-perayaan dll (Griffin, 2004:165). Dengan mempertahankan budaya organisasi maka setiap karyawan baru dalam sebuah organisasi akan dapat menerima dan mampu menyesuaikan diri sesuai dengan budaya organisasi yang ada.

Perilaku dan nilai-nilai yang dianut oleh seluruh anggota organisasi akan membentuk kenyamanan dalam bekerja. Budaya organisasi adalah sebuah strategi dalam memotivasi karyawan sehingga mampu bekerja secara maksimal. Budaya organisasi yang baik secara otomatis akan membentuk suatu keadaan yang mampu mendorong anggota organisasi untuk meningkatkan kemampuannya yang kemudian akan berpengaruh pada kesejahteraannya. Dapat dikatakan bahwa budaya organisasi merupakan faktor utama dalam meningkatkan kinerja melalui pemberian motivasi kerja kepada anggota organisasi tersebut (Sagita, 2018:74).

\section{Kinerja}

Kinerja (performance) mengacu kepada kadar pencapaian tugas-tugas yang terbentuk berdasarkan pekerjaan yang telah diselesaikan oleh karyawan (Simamora, 2004:339). Menurut Rivai (2004:309) kinerja adalah merupakan tindakan nyata yang ditunjukkan oleh setiap karyawan sebagai sebuah prestasi kerja yang dikerjakannya berdasarkan perannya masing-masing dalam perusahaan. Menurut Mangkunegara (2005:9) kinerja merupakan hasil kerja nyata atau prestasi kerja baik itu dari segi kualitas maupun kuantitas yang mampu dicapai oleh karyawan pada satuan periode waktu dalam mengerjakan tugasnya berdasarkan tanggung jawab yang diembannya. Sedangkan Yuniarsih dan Suwatno (2008:161) berpendapat bahwa kinerja adalah suatu prestasi nyata yang ditunjukkan oleh seseorang dalam organisasi setelah tugas dan perannya mampu diselesaikan. Kinerja menunjukkan bagaimana seorang karyawan mampu menyelesaikan sebuah pekerjaan. Sehingga dapat diambil kesimpulan bahwa kinerja merupakan hasil kerja seseorang dalam menyelesaikan tugas-tugas yang dibebankan kepadanya sesuai perannya masing-masing dalam organisasi perusahaan.

Yuniarsih dan Suwatno (2008:162) berpendapat bahwa ada lima aspek operasional yang mendorong tumbuhnya kinerja produktif, yaitu: budaya organisasi, desain, kepemimpinan organisasi, kondisi lingkungan, dan manajemen mutu. Menurut Timpe dalam Mangkunegara (2005:15) berpendapat bahwa kinerja dapat dipengaruhi oleh faktor internal maupun faktor eksternal. Faktor internal merupakan faktor yang berhubungan dengan sifat-sifat seseorang, misalnya: seseorang mempunyai kinerja yang baik dikarenakan ia merupakan tipe pekerja keras serta memiliki kemampuan yang tinggi. Faktor eksternal merupakan faktor-faktor yang dapat mempengaruhi kinerja seseorang yang disebabkan oleh kondisi lingkungan kerja, seperti bagaimana sikap, perilaku maupun tindakan yang ditunjukkan oleh bawahan, sesama rekan kerja maupun pimpinan, serta fasilitas kerja dan kondisi organisasi.

Yuniarsih dan Suwatno (2008:134) berpendapat bahwa ada tiga faktor yang menyebabkan seorang karyawan mempunyai kinerja rendah atau kurang memuaskan, yaitu: kurang mampu, kurang usaha, dan kondisi yang kurang menguntungkan. Menurut Davis dalam Mangkunegara (2007:67) faktor-faktor yang dapat mempengaruhi kinerja seseorang bisa dirumuskan sebagai berikut: 
a. Faktor kemampuan. Kemampuan (ability) seorang karyawan terdiri dari kemampuan potensial yang dimiliki (IQ) dan kemampuan yang nyata (knowledge + skill). Artinya, seorang pegawai yang mempunyai IQ melebihi rata-rata diikuti pendidikan yang mencukupi untuk mendukung jabatannya serta memiliki kemampuan untuk menyelesaikan pekerjaannya, akan mampu mencapai kinerja yang diinginkannya.

b. Faktor motivasi. Secara tidak langsung motivasi akan terbentuk melalui sikap seorang karyawan ketika menghadapi suatu situasi kerja. Motivasi merupakan suatu keadaan yang mampu mengarahkan diri seorang karyawan secara terarah dalam rangka mencapai target organisasi.

Penilaian kinerja merupakan suatu cara untuk memeriksa serta melakukan evaluasi dari kinerja seseorang secara teratur dan berkala. (Sedarmayanti, 2007:261). Penilaian kerja mengarah pada tatanan sistem yang sudah terstruktur dimana kegunaannnya adalah untuk melakukan penilaian, menghitung, dan mempengaruhi kondisi yang berhubungan dengan pekerjaan yang dilakukan, kehadiran, hasil kerja maupun perilaku karyawan (Rivai, 2005:309). Terdapat beberapa alasan untuk melakukan penilaian kinerja, yaitu:

a. Penilaian merupakan salah satu bagian yang tidak dapat terpisahkan dalam kegiatan proses manajemen kinerja pengusaha

b. Penilaian memberi kemungkinan adanya kerjasama antara atasan dan bawahan untuk melakukan koreksi atas temuan yang didapatkan pada saat penilaian kerja dan untuk menegaskan hal-hal yang telah dilakukan dengan benar oleh bawahan

c. Penilaian harus memperhatikan kelemahan dan kekuatan karyawan secara spesifik agar dapat selaras dengan rencana karier dari karyawan tersebut (Dessler, 2006:325326).

Dengan melakukan penilaian kinerja maka pimpinan dapat mengetahui bagaimana perilaku dan kinerja dari bawahannya, sehingga pimpinan dapat memberikan tindakan atas hasil yang didapatkan. Terdapat berbagai macam kendala dalam melakukan penilaian kinerja, salah satunya adalah kesalahan dalam menilai kinerja seseorang sehingga hasil yang didapatkan menjadi tidak akurat. Berikut ini terdapat beberapa cara untuk menghindari masalah dalam penilaian kerja, yaitu:

a. Peluang munculnya masalah beserta cara pemecahan masalahnya harus dipelajari dan dipahami.

b. Setiap perangkat penilaian memiliki pro dan kontra masing-masing, sehingga kita harus harus menggunakan perangkat penilaian kerja yang benar

c. Mempersiapkan penyelia sebelum melakukan penilaian dengan cara memberikan pelatihan sehingga dapat mengurangi terjadinya kesalahan seperti adanya kelonggaran, efek halo, maupun kecenderungan terpusat.

d. Menyimpan catatan harian, seimbang dengan usahanya (Dessler, 2006:342-343).

\section{METODOLOGI PENELITIAN}

Penelitian ini dilakukan dengan menggunakan metodologi deskriptif dan verifikatif. Statistik deskriptif merupakan penggunaan statistik yang mampu mendeskripsikan atau membuat gambaran berdasarkan hasil analisis data yang diperoleh akan tetapi hasil tersebut hanya berlaku spesifik dan tidak berlaku umum atau generalisasi (Sugiyono, 2017:232). Tujuan dari metode deskriptif adalah untuk mendeskripsikan bagaimana kondisi yang sedang berlangsung pada saat itu dan untuk mengetahui penyebab dari 
gejala tertentu. Penelitian ini mempunyai tujuan untuk mendapatkan gambaran bagaimana kondisi kepemimpinan visioner, budaya organisasi beserta kinerja yang terdapat pada pegawai Pemkot Cimahi. Tujuan penelitian verifikatif adalah untuk membuktikan kebenaran dari hipotesis berdasarkan data yang diperoleh dari lapangan, sehingga kita dapat mengetahui apakah ada pengaruh antara kepemimpinan visioner terhadap kinerja pegawai serta pengaruh budaya organisasi terhadap kinerja pegawai.

Pemkot Cimahi terdiri dari 19 instansi dimana total populasi pegawainya adalah sebanyak 1.365 orang. Adapun untuk mengetahui jumlah sampel yang diteliti yaitu menggunakan cara Slovin. Penelitian ini termasuk dalam kategori sosial, sehingga tingkat kesalahannya ditetapkan sebesar $10 \%$ adapun perhitungannya adalah sebagai berikut:

$$
\mathrm{n}=\frac{N}{1+N e^{2}}
$$

keterangan: $\mathrm{n}=$ jumlah sampel

$$
\begin{aligned}
& \mathrm{N}= \text { jumlah populasi } \\
& \mathrm{e}=\text { tingkat kesalahan sampel yang bisa ditolelir }(\mathrm{e}=0,1) \\
& \mathrm{n}=\frac{1365}{1+(1365)\left(0,1^{2}\right)} \\
& \mathrm{n}=\frac{1365}{14,65} \\
& \mathrm{n}=93,17 \approx 93
\end{aligned}
$$

Sehingga dapat diketahui bahwa jumlah sampel pegawai Pemkot Cimahi adalah sebanyak 93 orang.

Data penelitian ini diperoleh dengan menggunakan teknik-teknik sebagai berikut:

a. Angket (kuesioner), yaitu teknik mengumpulkan data menggunakan pertanyaan tertulis yang disebarkan kepada responden yang merupakan anggota sampel penelitian.

b. Wawancara, yaitu mengumpulkan informasi atau data dengan memberikan berbagai macam pertanyaan pada para pihak yang berkaitan dan memahami permasalahan penelitian mengenai kepemimpinan visioner, budaya organisasi dan kinerja pegawai.

c. Observasi, yaitu melakukan peninjauan dan pengamatan langsung terhadap objek yang diteliti.

Untuk membantu dalam proses pengolahan data menggunakan bantuan software statistik SPSS dan dan microsoft office excel.

\section{HASIL PENELITIAN}

Uji normalitas digunakan untuk menguji normal tidaknya sampel. Pengujian diadakan dengan maksud untuk melihat normal tidaknya sebaran data dianalisis dengan menggunakan Kolmogorov Smirnov dengan bantuan program SPSS. Kriteria pengujian normalitas data adalah ketika nilai probabilitas $>0.05$, maka data berdistribusi normal. Berdasarkan tabel 4.5 diperoleh nilai probabilitas variabel kepemimpinan visioner (X1) sebesar 0,174; nilai probabilitas variabel budaya organisasi (X2) sebesar 0,471; dan nilai probabilitas variabel kinerja pegawai (Y) sebesar 0,482. Hasil uji normalitas ini menunjukkan nilai probabilitas masing-masing variabel lebih besar dari 0,05 artinya data penelitian untuk variabel yang diteliti berdistribusi normal. 
Uji homogenitas dilakukan untuk mengetahui apakah dua/ lebih kelompok data sampel bersumber dari populasi yang memiliki kesamaan variasi. Hasil uji homogenitas menunjukkan bahwa nilai sign. di atas 0,05. Dengan demikian data penelitian tidak terjadi heterogenitas atau data variabel responden adalah homogen demikian dapat disimpulkan bahwa asumsi kehomogenan dapat terpenuhi. Penggunaan analisis regresi adalah untuk mendapatkan informasi apakah terdapat pengaruh dari kepemimpinan visioner terhadap kinerja pegawai, serta pengaruh budaya organisasi terhadap kinerja pegawai.

\section{Pengaruh Kepemimpinan Visioner terhadap Kinerja Pegawai}

Kriteria pengujian keberartian persamaan regresi adalah tolak Ho jika probabilitas lebih kecil dari alpha $=0,05$. Berdasarkan dari tabel pengujian signifikansi, nilai probabilitas sebagaimana ditunjukkan pada kolom Sig/Significance adalah 0,000 sehingga nilai probabilitasnya jauh lebih kecil dari 0,05. Dapat disimpulkan koefisien regresi signifikan, atau kepemimpinan visioner benar-benar memberikan pengaruh positif terhadap tingkat kinerja pegawai.

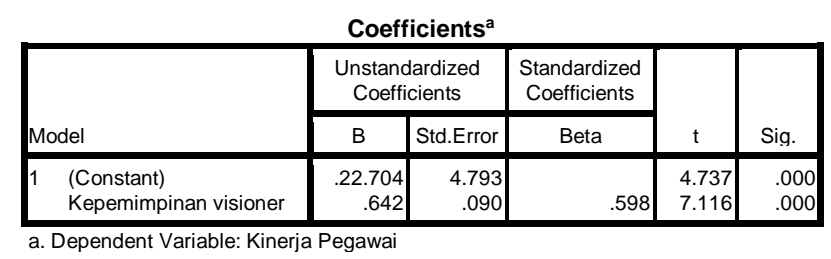

\section{Tabel 4.1. Persamaan Regresi Ŷ atas X1}

Berdasarkan Tabel persamaan regresi kepemimpinan visioner terhadap kinerja pegawai, sebagai berikut:

$$
\hat{\mathrm{Y}}=22,704+0,642 \mathrm{X} 1 \text {. }
$$

Dari hasil tersebut dapat pula ditentukan koefisien korelasi kepemimpinan visioner (X1) terhadap kinerja pegawai $(\hat{Y})$ yaitu sebesar 0,598 . Nilai tersebut menunjukkan bila besar derajat kekuatan hubungan antara variabel kepemimpinan visioner dengan variabel kinerja pegawai adalah cukup karena ada pada kisaran 0,40-0,599 berdasarkan tabel koefisien korelasi. Hal ini terjadi karena pada Pemkot Cimahi tidak semua kepala dinas memiliki kepemimpinan visioner yang mampu memberikan semangat dan dorongan kepada bawahannya.

Besarnya pengaruh dari kepemimpinan visioner terhadap kinerja pegawai disajikan dalam Tabel 4.2.

\begin{tabular}{|l|c|r|r|r|}
\hline Model & R & R Square & $\begin{array}{l}\text { Adjusted R } \\
\text { Square }\end{array}$ & $\begin{array}{r}\text { Std. Error of } \\
\text { the Estimate }\end{array}$ \\
\hline 1 & $.598^{\mathrm{a}}$ & .358 & .350 & 8.90317 \\
\hline
\end{tabular}

b. Dependent Variable: Kinerja Pegawai

Tabel 4.2. Koefisien Determinasi Pengaruh Kepemimpinan Visioner terhadap Kinerja Pegawai 
Berdasarkan hasil dari Tabel 4.2 dapat diketahui besarnya determinasi kepemimpinan visioner $(\mathrm{X} 1)$ terhadap variabel kinerja pegawai $(\hat{Y})$ adalah sebesar 0,358 atau $35,8 \%$, artinya tingkat kinerja pegawai dipengaruhi oleh kepemimpinan visioner sebesar 35,8\% sedangkan sisanya dipengaruhi oleh faktor lain.

Nilai pengaruh antara kepemimpinan visioner dengan kinerja pegawai di Pemkot Cimahi terhitung rendah. Walikota Cimahi merupakan pemimpin yang visioner karena mampu mengartikulasikan pandangan masa depan dengan berbagai program kerjanya yang telah membuah Kota Cimahi menjadi lebih maju. Akan tetapi dalam pelaksanaannya sebagai kepanjangan tangan walikota, tidak semua kepala dinas (SKPD/ SOPD) memiliki tipe kepemimpinan yang sama, sehingga ada yang tidak dapat mengartikulasi maksud dan keinginan dari walikota tersebut, sehingga semua visi yang dikemukakan walikota Cimahi tidak dapat tersampaikan kepada seluruh pegawai Pemkot Cimahi.

Hasil penelitian ini mengindikasikan bahwa semakin efektif kepemimpinan visioner, akan diikuti oleh semakin tingginya kinerja pegawai. Hal ini dapat diterangkan oleh persamaan regresi $\hat{Y}=22,704+0,642 X 1$. Dengan persamaan regresi tersebut dapat dijelaskan bahwa jika kepemimpinan visioner (X1) dengan kinerja pegawai (Ŷ) diukur dengan instrumen yang digunakan dalam penelitian ini, maka setiap perubahan skor kepemimpinan visioner sebesar satu satuan bisa diperkirakan bahwa skor kinerja organisasi akan mengalami perubahan sebesar 0,642 satuan menuju pada arah yang sama. Hasil penelitian inimemberikan beberapa informasi berikut: a) kepemimpinan visioner memberikan pengaruh yang berarti terhadap kinerja pegawai; b) salah satu cara agar dapat meningkatkan kinerja pegawai adalah dengan meningkatkan kepemimpinan visioner yang diterapkan oleh Pemkot Cimahi.

\section{Pengaruh Budaya Organisasi terhadap Kinerja Pegawai}

Kriteria pengujian keberartian persamaan regresi adalah tolak Ho jika probabilitas lebih kecil dari alpha $=0,05$. Berdasarkan tabel pengujian signifikansi nilai probabilitas sebagaimana ditunjukkan pada kolom Sig/Significance adalah 0,000 sehingga nilai probabilitas terlihat jauh lebih kecil dari 0,05. Dapat disimpulkan koefisien regresi signifikan, atau budaya organisasi benar-benar memberikan pengaruh positif terhadap tingkat kinerja pegawai.

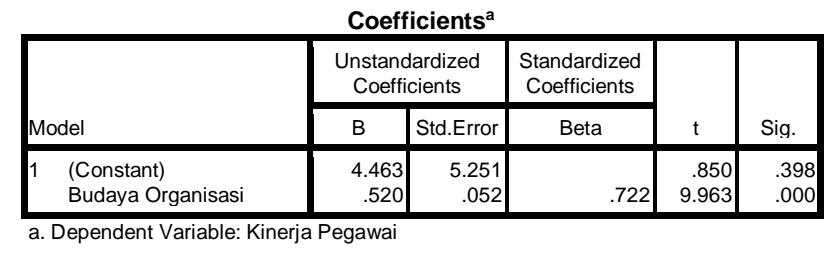

Tabel 4.3. Persamaan Regresi $\hat{Y}$ atas X2

Berdasarkan Tabel persamaan regresi diperoleh persamaan regresi budaya organisasi terhadap kinerja pegawai, sebagai berikut: 


$$
\hat{\mathrm{Y}}=4,463+0,520 \mathrm{X} 2 \text {. }
$$

Dari hasil tersebut dapat pula ditentukan koefisien korelasi budaya organisasi (X2) terhadap kinerja pegawai $(\hat{Y})$ yaitu sebesar 0,722 . Nilai tersebut menunjukkan bila besar derajat kekuatan hubungan antara variabel budaya organisasi dengan variabel kinerja pegawai adalah kuat karena ada pada kisaran 0,60-0,799 berdasarkan tabel koefisien korelasi. Hal ini terjadi karena pada Pemkot Cimahi sudah terbentuk budaya PNS yang kuat, akan tetapi masih perlu dilakukan pembenahan agar tercipta good governance.

Besarnya pengaruh dari budaya organisasi terhadap kinerja pegawai disajikan dalam Tabel 4.4.

\begin{tabular}{|l|c|r|r|r|}
\hline Model & $\mathrm{R}$ & $\mathrm{R}$ Square & $\begin{array}{c}\text { Adjusted R } \\
\text { Square }\end{array}$ & $\begin{array}{r}\text { Std. Error of } \\
\text { the Estimate }\end{array}$ \\
\hline 1 & $.722^{\mathrm{a}}$ & .522 & .516 & 7.68163 \\
\hline
\end{tabular}
a. Predictors: (Constant), Budaya Organisasi
b. Dependent Variable: Kinerja Pegawai

Tabel 4.4. Koefisien Determinasi Pengaruh Budaya Organisasi terhadap Kinerja Pegawai

Berdasarkan hasil dari Tabel 4.4 dapat diketahui besarnya determinasi budaya organisasi (X2) terhadap variabel kinerja pegawai $(\hat{Y})$ adalah sebesar 0,522 atau 52,2\%, artinya tingkat kinerja pegawai mendapatkan pengaruh dari budaya organisasi sebesar $52,2 \%$ sedangkan sisanya dipengaruhi oleh faktor lain.

Nilai pengaruh antara budaya organisasi dengan kinerja pegawai di Pemkot Cimahi tidak terlalu besar, hal ini dikarenakan budaya PNS di Pemkot Cimahi masih cukup terasa. Permasalahan ini harus segera diperbaiki agar dapat tercipta budaya organisasi yang baik serta agar dapat mewujudkan good governance seperti yang telah tertuang dalam rencana strategis Kota Cimahi.

Hasil penelitian ini mengindikasikan bahwa semakin kuat budaya organisasi maka akan diikuti oleh semakin tingginya kinerja organisasi. Hal ini dapat diterangkan oleh persamaan regresi $\hat{Y}=4,463+0,522 X 2$. Dengan persamaan regresi tersebut dapat dijelaskan bahwa jika budaya organisasi (X2) dengan kinerja pegawai $(\hat{Y})$ diukur dengan instrumen yang digunakan dalam penelitian ini, maka setiap perubahan nilai dari budaya organisasi sebesar satu satuan bisa diperkirakan nilai kinerja pegawai akan berubah sebesar 0,522 satuan menuju arah yang sama.

Hasil penelitian ini memberikan beberapa informasi berikut:

a. Budaya organisasi memberikan pengaruh yang berarti terhadap kinerja pegawai.

b. Salah satu cara agar dapat meningkatkan kinerja pegawai adalah dengan meningkatkan budaya organisasi.

\section{KESIMPULAN}

1. Kepemimpinan visioner memberikan pengaruh positif terhadap kinerja pegawai, sehingga apabila kepemimpinan visioner meningkat maka kinerja pegawai akan meningkat pula. Besarnya pengaruh kepemimpinan visioner pada kinerja pegawai adalah sebesar $35,8 \%$. 
2. Budaya organisasi memberikan pengaruh positif terhadap kinerja, sehingga apabila budaya organisasi meningkat maka kinerja pegawai akan meningkat pula. Besarnya pengaruh budaya organisasi pada kinerja pegawai adalah sebesar 52,2\%.

\section{Saran}

1. Seorang pemimpin diusahakan untuk memiliki kepemimpinan visioner agar visi dan misi organisasi dapat diimplementasikan kepada bawahannya, serta seorang pemimpin harus menganalisis lingkungan dan pengendalian di wilayahnya dalam rangka mengantisipasi masa depan.

2. Perlu ditingkatkan pengawasan kinerja pegawai serta diberikannya sanksi terhadap yang melanggar peraturan.

3. Perlu dilakukannya pembenahan budaya organisasi agar dapat tercipta budaya organisasi yang lebih baik lagi sehingga kinerja pegawai akan meningkat.

\section{DAFTAR PUSTAKA}

Dessler, Gary. (2006). Manajemen Sumber Daya Manusia Edisi Kesepuluh Jilid 1. Jakarta: PT Indeks.

Griffin, Ricky. (2004). Manajemen Jilid 1, Edisi 7. Jakarta: Erlangga.

Hartanto, Frans Mardi. (2009). Paradigma Baru Manajemen Indonesia: Menciptakan Nilai dengan Bertumpu pada Kebajikan dan Poteknsi Insani. Bandung: Mizan Pustaka.

Komariah, Aan dan Triatna, Cepi. (2005). Visionary Leadership: Menuju Sekolah Efektif. Jakarta: Bumi Aksara.

Mangkunegara, Anwar Prabu. (2005). Evaluasi Kinerja SDM. Bandung: PT. Refika Aditama.

Mangkunegara, Anwar Prabu. (2007). Manajemen Sumber Daya Manusia Perusahaan. Bandung: PT. Remaja Rosdakarya.

Priansa, Donni Juni. (2015). Manajemen SDM di Era Modern. Bandung: Alfabeta

Rivai, Veithzal. (2004). Kiat Memimpin dalam Abad ke-21. Jakarta: PT Raja Grafindo Persada.

Rivai, Veithzal. (2005). Manajemen Sumber Daya Manusia untuk Perusahaan. Jakarta: PT Raja Grafindo Persada.

Rivai, Veithzal dan Mulyadi, Deddy. (2010). Kepemimpinan dan Perilaku Organisasi. Jakarta: PT Raja Grafindo Persada.

Robbins, Stephen P. (2006). Perilaku Organisasi. Jakarta: PT Index. 
Sagita, Ayu Alinvia dkk. (2018). Pengaruh Budaya Organisasi terhadap Kinerja Karyawan dengan Motivasi Kerja Sebagai Variabel Mediator (Studi pada PT Astra Internasional, Tbk toyots Auto 2000 Cabang Sutoyo Malang). Jurnal Administrasi Bisnis $(J A B) \mid$ Vol. 57 No.1 April 2018|, 73-82.

Sedarmayanti. (2007). Manajemen Sumber Daya Manusia, Reformasi Birokrasi \& Manajemen Pegawai Negeri Sipil. Bandung: Refika Aditama.

Simamora, Henry. (2004). Manajemen Sumber Daya Manusia. Yogyakarta: STIE YKPN.

Sugiyono. (2017). Metode Penelitian Bisnis: Pendekatan Kuantitatif, Kualitatif, Kombinasi, dan $R \& D$. Bandung: Alfabeta.

Tasmara, Toto. (2002). Membudayakan Etos Kerja Islami. Jakarta: Gema Insani.

Thoha, Miftah. (2005). Manajemen Kepegawaian Sipil di Indonesia. Jakarta: Kencana.

Yuniarsih, Tjutju dan Suwatno. (2008). Manajemen Sumber Daya Manusia: Teori, Aplikasi dan Isu Penelitian. Bandung: Alfabeta. 